\title{
SECULARISM AND GUIDED DEMOCRACY
}

\author{
Innocent Ikechukwu Enweh* \\ http://dx.doi.org/10.4314/og.v14i1.5
}

\begin{abstract}
Secularism is the recognition of religion and politics as distinct and autonomous domains. As a doctrine of the state, it has in practice been taken to mean indifference to or rejection of religion, laicization, neutrality, disestablishment and recognition of cultural diversity. Rejection of secularism as antithetical to a nation's cultural traditions calls for special concern in a guided democratic system. The paper addresses the problem of disunity arising from rejection of secularism as diverse groups fan the politics of identity in Nigeria. The objective of the paper is to show that secularism as principle for structuring the organization of the state is a solid base for the unity of the state and a safeguard against drift into anarchy or theocracy. Adopting analytic and historical approaches, the paper argues that secularism is needed to stem the tide of reactionary and fanatical religious ideologies that threaten contemporary society. The paper concludes by noting that secularity of the state is to be upheld in Nigeria to ensure a viable and peaceful polity.
\end{abstract}

Key Words: Laïcism, Laicity, Disestablishment, Secularity, Neutrality.

\section{Introduction}

The growing disenchantment among the Nigerian population since 2017 got even more intensified as the nation approached the 2019 Elections. With the experience of hunger and unemployment among the populace coupled with the apathy on the part of the state in the face of untold suffering visited on the people by reckless and lawless bandits, talks about elections appeared to be mere echoes of a nightmare. As Academic Union of the Universities (ASUU) strike persisted and Labour Union threatened to join in the strike one wondered what would become of the elections. Prognosticators, clerics and lay persons alike expressed anxiety about the elections. While separatists, Indigenous People of Biafra (IPOB) of the South East and South South kept nursing the hope that their people will 
boycott the elections, the plague of Boko Haram kept ravaging the population of the North East and the lower ranks of the military as Nigeria squandered its youths and resources "in a murderous crossfire among those who wish to prevent change, those who wish modernization, and those who demand that the clock be turned back," to use the expression of Leon P. Baradt (2008:215). Meanwhile critics kept kicking against state indulgence in religious matters and expressed revulsion at government's donations and sponsorship of religious tourism. The truth however is that the level of failure on leadership in the society is such that many, including those in the academic world are overwhelmed by a feeling of frustration and helplessness. Divided along tribal, cultural, religious and ethnic lines, Nigeria like most developing nations has adopted a statist posture in its politics as it strives to unify its diverse constituent ethnic groups. The result is paternalistic authoritarianism parading as modern democracy just for rejecting authoritarian dictatorship.

The fear that the state's grip on power could degenerate into pure dictatorship and fascism led to wide spread reaction against the a-constitutional dismissal of the Chief Justice of the Federation, Justice Walter Onnoghen by the All Progressive Congress (APC) led government of Muhammad Buhari. The reactions from Civil Society Groups and religious bodies are serious pointers to the fact that other institutions are in complete control of some legitimate power. It is this form of political system in which political power is over centralized while other powers are left in the hands of other institutions that is identified as guided democracy. It is feared that if over centralization of political power continues unchecked in the country, it could provide lee-way for the installation of theocracy as radical religious ideologues infiltrate state institutions and government. This naturally creates the problem of disunity as rival religious and ethnic groups seek to protect their interest to the detriment of national cohesion. To forestall collapse into fascism and ensure smooth transition to liberal democracy the paper sets for its objective the upholding of secularism as principle structuring the organization of the state and the basis for national unity in a pluralistic religious society as Nigeria. Adopting historical and analytic methods, the paper shows that secularism, which it uses interchangeably with laicity, though referring primarily to the 
doctrine of separation of the authorities of the state and the Church has evolved to include laicization of social and cultural institutions and recognition of cultural diversity. It explores the meaning and full range of the uses of the word and restricts itself to the political application of the word in the context of guided democracy. The paper shows that the way in which state-church relation has existed in Nigeria risks drifting into theocracy given political Islam's penchant for fronting religion in all aspects of life. Here, it is argued that secularism provides secure and safe mode of state-church relationship that not only guards against drift into anarchy and possibly theocracy, but spurs the evolution into full liberal democracy, while providing solid basis for national unity.

\section{Secularism: Origin, Meaning and Dimensions}

The word «secularism » is of very recent origin with certain degree of fluidity in its usage that lends it readily to confusion and misunderstanding. The word is used interchangeably with laicism, and its cognate words lay, laity (laïcat in French), laicity and laicization. It is sometimes used as a synonym to neutrality. The word is often used in its dynamic form, secularization, to express a process of transition from one state to another: from religious to profane state. It is a word laden with a history characterized by conflict. It refers to a condition of withdrawal of the control and influence of the Church on determined sector of society. In his "Avant-Propos" Laot, L (1990:8) rightly remarks that secularism is not just a product of the force of external resistance to Catholicism but a divisive factor within the Catholic Church itself in the $19^{\text {th }}$ century. Originating in the context of the French Revolution, the French word "laicism" and the much tortured word "laïcity" have been used to make more explicitly the different shades of meaning of the word secularism. Jean Morange in D'Onorio, J-B:1989) argues that secularism is grounded in the following statements of Jesus: "My Kingdom is not of this world" (Jn.18:36) and "Give to Caesar what is Caesar's and to God what is God's" (Mt.22:21). He explains that the declaration of the French clergy in 1689 and the Gallicanism that resulted from that coupled with the international constitution of the Catholic Church and the declaration of human and citizen's rights on 26 August 1789 (p. 104) on the occasion of the French Revolution all reinforce secularism as a historical phenomenon. 
Exploring the meaning of the word laicity, as used in the French understanding of secularism, Joël-Benoït d'Onorio (1989: 25-26) traces its root to the Greek word "laikos", a term which according to him was ignored in antiquity but which Clement of Rome took up to designate the one who is not a priest. Thus the adjective lai which as a result became laic came to distinguish those who within the Christian community do not exercise religious responsibility vis-àvis those who are invested with the clerical state. Laicity is therefore etymologically anchored on the quality proper to the lay state of the faithful that are not invested with the sacred order. Canon law has conserved this distinction since its origin till date. The part confided to the lay faithful in the Church of the twentieth century in its pastoral action has become quite determinant that the lay faithful often taken as a body is referred to as the laity, "laïcat." On the contrary, the word laicity has never had a place in ecclesiastical language. It had to wait till the end of the $19^{\text {th }}$ century to make its appearance and only in political language. Given that the word was coined with a view to oppose the church, the word generated some reticence among its users. It was for this reason that the Church under the Pontificate of Pius XII strove to recuperate the word by way of re-appropriation when he spoke of healthy and legitimate laicity. Paul VI buttressed the same point at the beginning of his pontificate when he spoke of "correct laicity" of the earthly city. D'Onorio is therefore correct when he affirms that laicity or secularism is an idea that is specifically Catholic and French.

For the English speaking world, in Great Britain for one, secularism expressed itself in the movement of disestablishment. According to the document of the national Secular Society, "[t]he term 'establishment' and 'disestablishment' refer to the relationship between church and state. At its simplest, the former denotes a close and official connection between the two, while the latter refers to the process of severing such links" (https://www.secularism.org.uk). Ian Machin in Biagini, E. F (1996:137-138), remarks that "[t]he disestablishment campaign was at its most prominent in society and politics" from the 1869 (when the Voluntarists obtained the disestablishment of the Church of Ireland) until 1895. By 1914, it was already a weakened movement since the Labour Party had not been interested in it as was the case with the Liberal Party. The 
1902 Education Act had included catholics and even Ritualists on the rates and pressure for disestablishment began to give way to the alternative policy of spiritual independence. As Ian Machin puts it, "[t]he move to establish a democratic society has been reflected not only in the partial attainment of disestablishment but in the achievement of substantial religious self-government" (Biagini: 1996, pp.145-146). Events in recent times in England show that the value of liberalism in analyzing the relationship between religion and the state is gaining increasing attention. In a study, National Report: United Kingdom (pp.737-747), Bradney, A had argued that the traditional association of one's identity with religion has been altered in Great Britain as religion gradually becomes confined to "the private life of the citizens" except in the case of Northern Ireland where affinity to "either Catholic or Protestant Christianity remains a significant factor in both the private lives of individuals and in public life" (www.idrs.org). Julian Rivers in Cambridge Papers: Towards a Biblical Mind Volume 3, No.4 (1994) shows the various models of Church-State relations ranging from complete separation through neutral co-operation, symbolic commitment, establishment to complete unity.

As a movement secularism has its ancestry in anti-clericalism and found its expression in anti-religious feeling, expropriation of the Church and the audacity to proclaim a new world order governed by reason alone. While secularization designates political movement of secularism, laicization has come to be used when reference is to the socio-cultural aspect of the movement. These nuances which are given to this phenomenon are intended to reveal the dimensions it has taken. Expressed as laicization, it showed itself hostile to the Catholic Church. It involved government effort to control the system of education of its citizens in a way free from all forms of religious influence and control. This gave rise to a lot of conflict in most of the European nations, at the time, given the religious tradition that had nourished their educational and cultural development. The conflict had a lot of setback on the educational system as a whole. David Thomson (1966) remarks that in those days of serious controversy between the Church and the State Bismarck in his "May Laws" of 1873-75 "required state approval for the training and even the licensing of priests; suspended and 
imprisoned priests and bishops; and stiffened secular control over the system of public education (p. 366). It is alleged that some African countries, Ruanda and Zimbabwe, are making the same mistake Germany made under Bismarck, as well as other European nations made in those days of controversy in exaggerating the powers of the state by making it overflow its bounds. In Belgium and France the controversy was known as the "war of the schools," whereas in the Scandinavia, the stronghold of Lutheranism, "there was little friction between church and state" (ibid). Education at this period was characterized by indoctrination rather than "spirit of free inquiry and reflective thought" (p. 367).

In an attempt to avoid the brutal and violent relationship that characterized state-church relationship in the nineteenth century Europe, especially in Belgium, France, Germany, and Italy, the notion of separation of church and state has been interpreted to mean that the state should be neutral with respect to religious matters. It is not just that the state should not adopt any religion as state religion, but that it should be indifferent to religion. Neutralism is a philosophical position which maintains that "our critical thinking will only be likely to help us towards the truth if it is completely impartial and unbiased. Thus to think rightly about religious matters we must put aside all our commitments, or at least those commitments which are religiously 'loaded,' and adopt a completely neutral stance" (Evans, C. S: 1985, p.22). Neutrality of the state would mean non-intervention in matters relating to religion. It is a philosophical position comprising a political attitude. Of course, religious politics based on the institutional separation of the two spheres is fully in accord with democratic spirit as well as the teaching of the Church today. As D'Onorio once pointed out, it is just a reflection in the institution of the state of mind largely diffused in the people. As proclamation of the sovereignty of the state in the temporal order, the respective autonomy of the church and the state and respect for the freedom of conscience and of beliefs, secularism is rooted in liberty. But it is doubtful if its mode of expression in neutrality is practicable.

As Laurent Laot (1990) rightly remarked, secularism as a political movement began as anti-clericalism, a strong resistance to the 
involvement of the clergy in political affairs, and then it evolved into a movement of social transformation that underscored the independence of the social institutions from all religious influences and control. In practice it involved the emancipation of the army for the control of ecclesiastical authority, assertion of the independence of the administrative and civil services from the Church and the freedom of judges from the influence and control of religion. The notion of secular state meant a profound delimitation between the temporal and the spiritual. The state became a-theist, not in the sense of promoting philosophical or practical atheism, but in the sense of indifference or neutrality with regard to God-question. The state places itself over and above religious opinions, considering itself incompetent and indifferent à propos the question of God. Before the state, every religion is valid, and no religion is socially necessary; religions are just by the way. To the state it belongs to ensure that full religious and philosophical, personal and collective liberty are guaranteed in the society. Religious beliefs are considered a matter of individual choice; one is free to believe or not to believe in God. It belongs to the group to organize its mode of practices in conformity with its doctrines. It is on account of this kind of attitude to religions and religious practice that secularism has come to be identified as legal expression of the liberty of the act of faith (pp. 31-33). Having taken grip of the state, secularism diffused itself through social institutions (families, schools, hospitals, homes and prisons) till it became itself the very rationality of the state. Today it has become the value and the structuring principle of political thought and behaviour (p.39). It is now all about the recognition of cultural diversity. It aims at all forms of cultural or political discrimination in societal life (p. 43).

\section{The Typology of Secularism}

Secularism as a word developed in the context of political conflict and as such has been negatively defined. It was with the passage of time that it came to be filled with ideological content. As a historical phenomenon it refers to doctrine of the separation of the two powers, the state and the church following the declaration of the French Clergy in 1689 and the Gallicanism that resulted from it. As a movement it drew its force from the French Revolution, particularly the declaration on human and citizen rights of 26 August 
1789. It was championed by free thinkers who wishing to create a state without religion sought to stripe the Church of all its influences in the life of the society ensuring that no religion was legally adopted by the state. The state was therefore to be ideologically neutral in all religious matters. It involved the suppression of religion in the public space and eventually pushing completely back to the domain of private and domestic life. Although, at first it was assumed to be a principle of neutrality and in some case of pluralism (Morange, J in D'Onorio, J-B:1989, p113), in practice it has expressed itself in varied ways as antagonistic, discriminatory, militant and hostile to the catholic church. In this regard it implies two things at the same time: "deconfessionalisation" of teaching and exclusion of religion (Sicard, G in D'Onorio, J-B: 1989, p. 76). It means that the so-called neutrality proclaimed by the state did not even conceal the masqued hostility. It is on this account that in 1945 the Assembly of Cardinals and Bishops of France published a solemn declaration in which it tried to clarify the different senses of the secularity of the state. These senses contained in the Declaration de 13 novembre 1945, D.C. $n^{\circ} 955$ (1946), col. 6 in Onorio, J-B (1989, p. 58) constitute what we designate here as the typology of secularism, and they are as follows:

(a). Laicty (secularity) of the state understood as the sovereign autonomy of the state in its sphere of temporal order: its right to control all political, judicial, administrative, financial, military organization of the temporal society, and in a more general manner, all that concern political and economic skill.

(b). Laicity (secularity) of the state would also mean that in a religiously pluralistic society the state should allow each citizen to freely practice his religion.

(c ) Laicity (secularity) of the state could also be understood as a philosophical doctrine that contains all materialistic and atheistic conception of human life and society sponsored by a political system of government that seeks to impose the said conception on its functionaries even in their private life, in state schools and the entire nation.

(d). Secularity of the state has also been presented as the will of the state never to subordinate itself to any superior morality and only to recognize its own interest. 
The first two senses ( $a$ \& b) of laicity or secularity of the state are what this paper has adopted, whereas the last two (c \& d) are referred to as laicism, and are rejected by this paper as unacceptable. These have no place in modern democratic society since they would violate freedom of religion and conscience. These brands of secularism, or preferably laicity are dogmatic and claim that whatever is outside them cannot be reasonable and so would belong to the darkness of the spirit. This is a form of phobia for all form of religion. While secularism understood as phobia for all forms of spirituality antagonizes the church, the rise of religious fanaticism obliges the church to stand out in the public domain. The Church can no longer remain silent or be confined to the recesses of private conscience. The truth is that secularism has not succeeded in marginalizing religion. As Jean-Michel de Forges put it, the modern spirit may have triumphed but without ensuring the disappearance of the spirit of faith. With Islam the situation is even different for Islam does not admit of the autonomy of the civil from the religious. Born and nourished against the background of Christian culture, secularism in its belligerent outfit (as laicism) fought to reduce the influence of Christianity, but today it is at sea with regard to containing Islam. It is paradoxical to think of a state that audaciously proclaims secularism, yet at the same time unable to resolve the social problems caused by a religiousity that runs contrary to contemporary mentality as customary attitudes. The experience of France since the 1980s has confounded the arrogance of la laïcite à la française.

\section{Secularism and Modernity}

Modernity in France made secularism a dogma, an authentic taboo. It was a Republican dogma. Although it brought liberty, it had not always engendered equality. After two centuries of confrontation between the Church and free thinkers or the apostles of secularism, it is becoming obvious that secularism has not succeeded in rooting out religion. Writing in the context of France, J-M de Forges in D'Onorio, J-B (1989, p.30) notes that the $19^{\text {th }}$ century emerging from the last decades of the $17^{\text {th }}$ century invented a modernity that was built against the Church, its moral doctrine and its social mission: the reign of reason against the reign of God, the primacy of 
man against the primacy of God, the sacralization of the law of the state against the sacralisation of the law of God. Inspired by French Revolution and the Enlightenment, secularism claims that man does not need God; human reason suffices. Man, it insists, is capable of saving himself; he is the master of history. It sees in religion the source of hatred, violence, suffering and ruin. As it were French Republic was not just demanding for the neutrality and independence of civil society from religion, it needed an ideology to replace it; it needed a moral and virtually a religion. Thus secularism came as a systematic attack on the Catholic Church, armed with the will to mutilate the theological virtues of faith, hope and charity which it took up in an inverse order. At first it was not easy for the free thinkers who engineered secularism. They even experienced division among themselves as some minority spiritualists saw in Deism a certain insistence on maintaining obligations toward God. It soon developed into a sect with August Comte as its philosopher and Franc masonry its soul. Thus by its excesses, dogmatic secularism gave rise to discriminatory secularism (D’Onorio: 1989, pp.32-34)

\section{Secularism of Conciliation: The Nigerian Experience}

The juridical status of secularism in Nigeria is informed by its history. Being a colony of British Empire, the state-church relationship takes after the model in place in the Empire, at least in a formal way. In England, the Anglican Church was considered an element in the structuring of the society with the Anglican Church having recognized public rights (where the minister of cult was placed at the same rank as the magistrate and Bishops sitting in double capacity in the House of Lords) and subordination. In accordance with Statute of the National Assembly of the Church that has been in force since 1919, the article of faith cannot be modified without the consent of the Parliament (B. D. Dupuy, "Anglicanisme", dans l'Encyclopaedia universalis, vol. I, Paris, 1980 , p. 1069-1071 in Laot, L (1990, p.27 footnote 9). To a large extent this appears to represent the Napoleonian model enshrined in the Concordat of 1801-1802 except that the state could still interfere in matters relating to dogma. The Anglican missionaries, C. M. S, had already existed in Nigeria for more than half a century by the time of Amalgamation in 1914. The colonial government in Lagos, 
as early as between 1870 and 1876, is recognized to have "made spasmodic attempts to assist some of the missions in their educational work" (Fafunwa, A. B: 1982, p.93). So it could be said that from the start the state had a convivial relationship with religious authorities even if the model of state-church relation in England would not be put in place in the colony given the plurality of religious affiliations: Catholic, Protestant of different shades and colours, Islam and African Traditional Religions. Secularism would mean actual institutional and cultural autonomy of religion and politics.

In principle, in Nigeria today, state-church relationship is generally characterized by neutral co-operation and symbolic commitment. The state as well as the church recognizes its specific domain of expertise and competence and tries to respect it. The state goes even much further to work with religions such as Islam and Christianity. God is seen to have a place in the Constitution, the National Pledge, National Anthem and in the oath of office. Secularism has a place in Nigeria as a constitutional principle of state-church relationship even though, in practice there seems to exist, with some regime or administration, a degree of establishment with regard to Islam. In Northern Nigeria where Moslems form the majority of the population, there is a tendency to the model of complete unity as sharia law is recognized as part of the tradition of the people. This model of relationship has continued to be a source of religious conflict, violence and persecution and socio-political instability. But Nigeria is not a confessional state in the sense of adopting any particular religion as the religion of the state. As a religiously pluralistic society, Nigerian state ought to respect the diverse religious confessions in the land and should allow and also encourage the adherents of the various faith confessions to practice their faith in their various life situations. The Constitution of the Federal Republic of Nigeria recognizes the place of God in the affairs of men. As already mentioned, the nation in its national anthem invokes the God of creation. While confessing the existence of God and admitting the reality of the place of God in human affairs, the Nigeria state does not identify itself with any particular religion. The state approves of institutional structures in the state that are put in place to enhance the practice of faith: there are chaplaincies in the army, in the police, in schools, hospitals, prisons 
and even in the state houses. There is also state support for construction of religious edifices such as mosques, churches, schools and hospitals, charity institutions like old peoples' home, motherless babies' home and rehabilitation centers for prisoners and victims of leprosy. The Nigeria state also engages is sponsorship of pilgrimages and religious tourism. Religious education is part and parcel of the curriculum of education for the teeming population of Nigerian children and youths. And religious feasts are part of national holidays in the nation's calendar. Even during the national day celebrations, prayers are offered in churches and mosques for the good of the land. The President would generally end his address to the nation by invoking God's protection on the land with such statements as "... God bless the Federal Republic of Nigeria." In a most recent event,Nochiri, I, a reporter writing for Sunday Vanguard on 27 January 2019 notes that the Ag Chief Justice of Nigeria, Justice Tanko Muhammad on Saturday, 26 January, 2019, on the occasion of the swearing in of 250 Election Petition Tribunals Judges reminded the Judges that by the oath they swore they are "ultimately responsible" to God Almighty since the oath is "a solemn appeal to Almighty God." Encouraging them on the need to brace up to the challenge of their new responsibility he said, "... I implore you to discharge this onerous duty diligently and with the fear of God Almighty." He concluded his exhortation by expressing his prayerful wish for them in these words: "I encourage you to uphold and enhance the honour, integrity and standing of the judiciary and I pray that the Almighty Allah will bestow upon you strength, good health and wisdom and capabilities in the performance of your duties" (Sunday Vanguard, January 27, 2019: 6). So, it is not in doubt that religion is part of Nation's life since it is the source of morality and ethics without which the rule of law on which democracy is anchored remains itself shaky.

The timely and courageous interventions of religious leaders in the political life of the nation are also signs of the healthy and mutual relationship of the state authorities with the religious leaders. Therefore, secularism in Nigeria is not that of absolute separation nor is it "laïcité integriste" to use French expression. It is equally not just a type of neutralism. The fact of experience shows that total separation of the state authorities and religious leaders would be unlivable, just as integral secularism would be impracticable. So 
also is ignoring each other in the name of neutrality impossible. Secularism in Nigeria involves reciprocal, respectful and legitimate relationship between the state and the religious bodies. Although as doctrine of the state secularism may call for neutrality on the part of the state, it is to be remarked that neutrality has to be nuanced.

It does happen that from time to time one witnesses the upsurge of secularism of neutrality which is promoted in schools by some who are intolerant of certain religious emblems (crucifix, scapular, medals) either because of their own religious confession or because they wish to appear as avant-garde of modernity. Before the fall of Soviet Union academics of Marxist political extraction were strong spokesmen of secularism in the neutralist sense since their atheistic opinion would not appeal to majority of Nigerians. Today, secularism may have to find support in the double discour of members of sects and secret cults. When such people find themselves in positions of influence with regard to education policy, they easily align themselves with some self-styled atheists and interest groups to replace religious education, particularly Christian religious education with civics. In the South East, the take-over of Church schools by the state, following the end of the civil war provided occasion for unhealthy and discriminatory secularism as iconoclasts promoted the exclusion of religious emblems and religious education from schools. The Administration of Ukpabi Asika and the state education commission under Dr. Offia Nwali were notorious for their anti-catholic behaviours. Nwali is reputed for desecrating a chapel in the hospital jointly owned by the state and the church. These measures which discredit the Christian faith have succeeded in providing lee-way for promotion of Islam in Nigeria as Moslems insist on religious integralism. The proliferation of community and state schools has contributed enormously to dissuading parents from sending their children to boarding house where they could be brought up with Christian discipline and morality. However, in the face of failure of the educational system, government's encouragement of private individuals and organizations to set up schools has made it possible for the church to launch back into promotion of Christian education through schools.

Although we have described the constitutional status of secularism in Nigeria as convivial, it needs to be added that on a number of occasions, the status of religion has provoked passionate 
and acrimonious relationships in the polity. At one time the debate turned around the status of non-Muslim minority in the north which the Muslins perceive as Islamic society. At other times it bothered on question of erecting a Federal Sharia Court of Appeal to adjudicate over matters emanating from the state Sharia court. In the late $70 \mathrm{~s}$, the illegitimate military regime of General Olusegun Obasanjo had to contend with some of these problems. From the late 80 s to early $90 \mathrm{~s}$, the regime of General Ibrahim Babangida which was characterized by manipulation tried to create a religious divide in the country by heating up the polity with the claim over the admission of Nigeria in the Organization of Islamic Conference (O.I.C) in 1986 (Kukah, M. H: 2007, pp. 102-104). At other times, it is members of interests group such as Federation of Muslim Women (FOMWAN) who have tried to politicized religion by pushing for the establishment of sharia court in the South. The reactionary ideology of militant Boko Haram insurgents has once again introduced religion into the national question, more than ever, politicians appear to be more realistic in politicking. Secularism as laicization has always been a source of disquiet for most developing nations, Nigeria for one. The fear stems from the assumption that Western culture and tradition is quite different from our national way of life. Besides, there is always the anxiety that adopting western values will lead to the eradication of Nigerian indigenous cultural values. Secularism is modernity, and modernity is western. So, it is argued that if Nigeria is to preserve her indigenous cultural norms and values, she must be careful, to say the least. This attitude is even more pronounced among cultures that are rooted in Islamic tradition. Islam does not recognize the separation of religion from the state. It means that adopting secularism tantamount to deIslamization. In Nigeria where political Islam has always been associated with the "Caliphate will to power," secularism will always be suspect. It is alleged that Boko Haram has infiltrated government institutions (Chinweizu: 2015, p.11-13) and that the upsurge of Islamic radical movements in Nigeria is expressive of the Jihadism of the "Caliphate colonialism." Jihadism is a threat to secularism without which there could be no true democracy; and guided democracy is a potential ally to Jihadism as religious form of fascism and totalitarianism. 


\section{Secularism and Guided Democracy}

So many reasons have been adduced to explain the failure of democracy in developing nations in general, and in Nigeria in particular. For some, democracy has failed in Africa because of the nature and perception of the state itself. In this regard colonialism has continued to be an explanatory factor as the elites point to external control on the internal running of the government. Kukah, M; H. (2007:16-17) dismisses this view by pointing out that reactions to colonialism is dependent on the cultural baggage of the colonized people. According to him Iran used Islam to free itself from western hegemony just as Latin America used liberation theology. It is not that Islam or Christianity in these countries are different from what it is in Nigeria or Africa. The real difference lies in the fact that clientelism characterizes the relationship of the state and the citizens in Nigeria. This situation is aggravated by the fact that in the face of the plurality of ethnic nationalities that characterizes Nigeria, as it is the case with many developing nations, it is believed that a strong state, that is, centralization of political powers is needed as a cohesive force to ensure the unity of the constituent units. With the attraction for democracy, following the collapse of the Soviet Union, many nations since the 90s have tried to install a democratic regime but these attempts have not yielded significant dividends in many African nations. What is however common to most of the attempts at democratic regime is what has been described as benevolent paternalism or soft authoritarianism. These new forms of democratic practices have been classified as "guided democracies." Within the political circle in Nigeria this form of democracy is justified as being home grown. Kukah, M. H (2007:12) dismisses the idea of "home grown democracy" as one of those fallacies that have gained currency in Nigeria since the military dictatorship. According to him it was a view peddled by "military apologists masquerading as academics."

Guided democracy is a form of totalitarianism where political power is entirely vested on the state while the citizens are reduced to mere subjects of the state whose opinions do not really count in matters relating to political ordering of the state. Holding on to the basic truth about human nature that dictated specific social arrangements, those in power assume that a dictatorial and 
enlightened elite could help to institute these practices. The people are only considered worthy of trust only if they are properly educated. The assumption is that it would be running grave risk allowing the people to debate public policy issues given that they are ignorant of politics and state matters. To save them from falling prey to intellectual exploitation by scoundrels, they are shielded from involvement in political decisions. In a situation as this, it is believed that a temporal dictatorship is needed until the people's minds are cleansed of the misconceptions from which they suffered as a result of previous oppressive government, the military in the case of Nigeria. In a totalitarian or guided democracy, the traditional idea of a harmony of interest replaces the idea of common good. In the mind of those in power, the common good is nothing objectively established since it belongs to each ruling party or faction to determine what in its opinion is good for all. In Nigeria, that the opinions of the citizens do not count is demonstrated in electoral malpractices and crimes often sponsored by political elites, the socalled stakeholders. It is for the same reason that there is much resistance to restructuring and devolution of power that are found to account for the dearth of progress in the country. The danger in this kind of political arrangement is that it could easily degenerate into outright authoritarianism when power gets into the hands of bigots. Fukuyama F (2012) tells us that a state that considers itself supreme in all respect can violet property right by confiscating the property of its citizen, or of foreigner who are doing business with it. In such systems elections are stage managed. The Rusian experience says it all: Since the arrival of Vladimir Putin in power, the elites, the President inclusive, are said to break the law with impunity (pp. 248249). Russia under Putin has become what some political scientists label "an electoral authoritarian regime" (p. 387). In the words of Baradat, L. P (2008:108) "popular government is the essence of a democratic system." So, essential as centralization of political power is, without pluralism which requires that political powers be widely held in society, government becomes extractive and stifles the processes of empowerment. The experience of South Korea testifies to how the political reforms which was initiated after the assassination of General Park "led to the consolidation of the pluralistic democracy after 1992" (Acemoglu, D and Robinson, J. A: 2013, p.93). 
In Nigeria, the dismissal of the Chief Justice of the Federation Walter Onnoghen generated reactions that confirm the fact that it possible in the exercise of centralized power to degenerate into despotism. Punch Editorial on Saturday 26 January, 2019 decried similar incidents of violation of the constitution and the spirit of democracy and called on members of the civil society to rise and nip in the bud what" according to the editorial, "is turning out to be a gradual but seemingly inexorable descent into full blown dictatorship." The reaction from international community (USA, EU), legal luminaries, civil society groups and other professionals show that the dividing line between guided democracy and dictatorship is very slim and leaders can easily confuse the two if there are no proper constitutional checks. In a Sunday Vanguard Newspaper report Uja, E. Anaba, I., Dumu, P., Onochiri, I. et al (January 27, 2019, pp. 4-6) present Governor Henry Seriake Dickson as describing the action of the President as "a sad commentary on democracy in Nigeria." For the Nigerian Christian Elders' Forum (NCEF) it is "a flagrant violation of the constitution" and "a jihard against the nation's judiciary." The Human Right lawyer Emmanuel Ogebe says the action amounts to "executive criminality." A Senior Advocate of Nigeria (SAN), Sylva Oguemoh calls it "a crass display of executive lawlessness that must not be allowed to stand." For Chino Obiagwu (SAN), it is "an attack on the independence of the judiciary and of the legal profession, an utter disregard of the rule of law and a threat to Nigeria's Constitutional Democracy." In another reaction, a coalition of 70 Civil Society Organizations in a statement signed by Mr Clement Nwankwo describes the president's action as "a major threat to Nigeria's democracy and a descent into constitutional anarchy." According to Nwankwo "President Buhari has breached the Constitution and has acted with impunity and disdain for the rule of law, due process and constitutionality." These observations and remarks point to the precarity of guided democracy. It is only by strict application of the rule of law that guided democracy could be prevented from degenerating into fascism and tyranny. Despite the fact that there appears to be evidence to show that the service chief, Justice Walter Onnoghen was 'dubious,' for want of due process and constitutionality the 
Ogirisi: a new journal of African studies vol. 142018

Chief Executive of the Federal, President Muhammad Buhari, attracted the odium of the people.

\section{The Need to Uphold Secularism}

It is to be remarked that now is a most favourable time for instituting a secularist culture with regard to politics. Secularity of the state does not in any way mean disregard for religion or denial of God's existence or the place of religion in human life. It only means that state and religion should be recognized for what they are. Driving its origin from the modern idea that power belongs to the people, as against the ancient and traditional view that God is the source of the authority of kings, secularism is grounded on the politics of social contract in which leaders are accountable to the people whose mandate they enjoy. To refuse secularism is to give in to a system of social and political organization that promotes paternalistic leadership in which authority and obedience are essential political virtues. On the contrary, secularism opens up to a democratic system which is characterized by equality, freedom and pursuit of happiness. The current social situation demands that secularism be given the place it immediately deserves in the polity.

First, the fact that there is no corresponding relationship between rise in religious favour and practice of virtue in civil society requires that a critical look should be taken with regard to the place of religion in the society. When religion overflows its bounds, it becomes obstructive on human progress. The experience of medieval Europe is there to teach us. In a society with diverse cultural, religious and social traditions as is the case with postcolonial independent states, the dogmatic voice of religion would be intolerant to admit of compromises and dialogue which are needed for fostering understanding and peace among the constituent groups. Much more worrisome is where as it is often the case today, political leaders tend to enhance their legitimacy by turning to religious charlatans to obtain divine mandate for political office. Their romance with clerics and marabou gives the impression that they have been anointed by God or some divinity to occupy the position they seek and find themselves in. This secular messianism leads to abdication of responsibility on the part of the leader and the people. The people are turned into yeomen as they project a kind of infallibility on their leaders. The leader is assumed to be always 
right whereas the duty of the people is only to obey. Unconsciously the people imbibe the idea that they must have to wait on God to undo the wrong of their leaders by appointing another leader. It no longer crosses their mind that these leaders were entrusted to the positions they occupy, thanks to their votes, their mandate, and as such could be relieved of their post through the power of votes. The installation of secularism understood as recognition of and respect for domains of competence specific to the state and to religion respectively obliges the state to act only within the sphere of the temporal order.

Second, the rise in fundamentalism has, since the Islamic revolution of 1979 projected religious identity in a way that conflicts, in certain situation, with national identity. Religious identity has tended to favour religious intolerance, thus engendering conflict and violence in the society. Sometimes, religious fundamentalism degenerates into outright anarchism of militant hue. It is only by upholding and defending the secularity of the state and the autonomy of religions that these hordes could be put in check and the polity sanitized by the enthronement of true democracy. Although secularism, particularly the convivial type, is compatible with Christian principles, it can as well be obstructive of societal life when it assumes absolute antagonistic stance. Imbibing secularism as a political value and as principle structuring the organization of the state will help to eliminate the present tendency to factor in religious consideration into social identification of citizens and in the process of giving access to public offices. Given the diversity of religious affiliations in Nigeria, secularism provides new basis for national unity. As Laurent Laot remarks, the setting aside of all religious questions in the organization of life in the state is thus an instrument adapted to this objective. So it is the unity of the state that justifies secularization in the context of religious pluralism.

Third, that secularism is the recognition and affirmation of difference in respect of the two domains of existence, spiritual or religious and secular is not to be confused with the question of morality and ethics. The question of morality belongs to the domain of value. Secularism has no contribution to make with regard to value. It is in the field of ethics that the ideal is translated into life. Such is the position of Cardinal Paul Poupard in a Preface, to the book, La Laïcité au défi de la modernité, edited by Joël-Benoi 
d'ONORIO (1989). Continuing his remarks the Cardinal notes that secularism can never furnish one reasons to live. On the contrary, it always needs to give to each person the possibility, not just to live it, but also to explain and share it. A secular state is such that it cannot determine the frontier of good and evil nor inspire love of the good and hatred for evil in the citizen, much less motivating them to practice these virtues without which, as experience shows, it would be impossible to live in a democratic system. The awareness of this incompetence in this regard is what informs the negative definition of secularism as the refusal of the state to unduly intervene in the private life of the individual where each is placed before God and his conscience (pp.10-11). It is however by admitting its incompetence in the domain of ethics as well as recognizing and respecting those who have the competence that the secular state can survive. Those who contest this view assume that man is the measure of all things. Protagoras thought as much. But the question is, how could one feel obliged by external norm if one were to consider oneself as the measure of all things, while at the same time recognizing in others the same absolute measure? It is demanded therefore that the unconditional respect for certain norms requires some measure of transcendence. It is this transcendence that permits even those who claim to be atheist to have moral principle; that is an ultimate value to which others find their source and are subordinated.

Fourth, in a pluri-religious culture as Nigeria, secularism is needed to contain unity in diversity. In the past, particularly in culture with one religion, it was religion that provided the binding force in a nation's life as nationality is identified with religion. In modern states with multiplicity of religions it is only by giving secularism a legal framework that difference among the various religions could be protected and respected. It means in effect that secularism itself becomes the new ground for living together; it goes beyond mere tolerance to affirmation of and respect for difference without which it will be impossible to live together.

Recommendations

1. The state should dissociate itself from establishment and, or patronizing of any particular religion. Where patronage of religions is accepted, it should be on the basis of even handed co-operation. 
Enweh: Secularism and Guided Democracy

2. Sponsorship of pilgrimages and building of places of worship and religious cult should not be seen to favour one religion more than others.

3. Religious laws should be restricted, as much as necessary, to the domain of individual conscience and should not be allowed to interfere with state legislations that are intended for the common good.

4. Secularism is to be upheld as principle for structuring the organization of the state, in this way, religious politics of identity is dissolved and citizenship projected as ideology of national integration. In this way national unity is enhanced and guaranteed.

5. Complete unity of state and religion has to be shunned to accommodate plurality of religious faith expressions and freedom of conscience which safeguards peace and harmony in the state.

\section{Conclusion}

The foregoing study has shown that secularism as principle structuring the organization of the state and as basis for unity of state is very important in modern state with its characteristic pluralism. In pre-modern societies, religion played a unifying role in defining identity and citizenship, but with colonial creation of states which entailed amalgamating diverse ethnic nationalities, culture and religion it has become impossible for religion to play its ancient role. Founded on the values and ideals of modernity and aspiring to the ideals of the system of political organization that characterizes modernity, namely democracy, it has become impossible to run the state without the adoption of secularism as a philosophical framework. Secularism as discussed above is primarily a political attitude or philosophy which recognizes and insists on the autonomy of state and religion in respect of their different domains of competences. The paper has elaborated on the various senses and dimensions of the use of the word secularism with special reference to recognized difference in approach with regard to time, place and circumstance. Given the peculiarity of the practice of democracy in developing nations, and here the paper focuses on Nigerian nation, it has been argued that secularism is particularly important in a guided democratic state if it is to transition into liberal democracy. Taking 
Ogirisi: a new journal of African studies vol. 142018 into cognizance the fact that neutrality as a philosophical position is difficult, if not impossible in practical affairs, and given that the state on its own merit cannot provide for an ethics that is transcendentally grounded, secularism helps to ensure reasonable control of state leadership against possible slip into tyranny and fascism and spur full development of democracy, namely, liberal democracy.

*Innocent Ikechukwu Enweh, PhD, Department of Philosophy, University of Nigeria, Nsukka,innnofficebox@gmail.com 


\section{REFERENCES}

Abelès, M (Editeur). (1991. Faire la Politique, Paris: Autrement Éditions

Acemoglu, D \& Robinson, J. A. (2013). Why Nations Fail. The Origins of Power, Prosperity and Poverty, London : Profile Books Ltd

Baradat, L. P. (2006). Political Ideologies. Their Origins and Impact, New Delhi: Prentice-Hall of India

Chinweizu. (2015). 2015 Presidential Election Issues Part II of «2015- Between Liberation and Slavery, » A Contribution to the Abuja Symposium on 'National Confab and the 2015 General Electioins' on Monday, $2^{\text {nd }}$ February 2015, held at Lagos/Osun Hall, Transcorp Hilton Hotel.

D’Onorio, J-B. (1990). La Crise de la Laicité, D’Onorio, J-B, (Editor). La Laïcité au défi de la Mordernité, Paris Tequi.

De Forges, J-M. L. (1990). La Réligion dans l'École Laîque, D’Onorio, J-B, (Editor), La Laîcité au défi de la Modernité, Paris : Téqui

Evans, C. S. (195). Philosophy of Religion. Thinking About Faith, Illinois: InterVersity Press.

Fafunwa, A. Babs. (1982). History of Education in Nigeria, London: George Allen \& Unwin

Fukuyama, F. (2012). The Origins of Political Order. From Prehuman Times to the French Revolution, London: Profile Books

Machin, I. (1996). Disestablishment and Democracy, c.1849 - 1930, Biagini, E. F. (Editor), Citizenship and Community Liberals, radicals and collective identities in the British Isles, $1865-$ 1931, Cambridge: University Press.

Kukah, M. H. (2007). Democracy and Civil Society in Nigeria, Ibadan: Spectrum Books Limited

Kukah, M. H. (2011). Witness to Justice. An Insider's Account of Nigeria's Truth Commission, Ibadan: Bookcraft

Loat, L. (1990). Catholicism, Politique, Laïcité, Paris: Les Éditions Ouvrières

Morange, J. (1990). La Laïcité Selon le Droit de la IIIe À la Ve République. D’Onorio, J-B, (Editor) La Laïcité au défi de la Modernité, Paris : Tequi 
Ogirisi: a new journal of African studies vol. 142018

Nochiri, I. (January 27, 2019). "Supreme Court Judges Boycott Ag CJN's First Official Assignment as Muhammad Swears-in 250 Election Petition Tribunals," Sunday Vanguard Vol. 24 No. 15934: 6

Poupard, P. (1990). La Laïcité et Étique. D’Onorio, J-B, (Editor), La Laïcité au défi de la Modernité, Paris : Tequi.

Sicard, G. (1990). La Laïcité de Jule Ferry, D’Onorio, J-B, (Editor), La Laïcité au défi de la Modernité, Paris : Tequi

Thomson, D. (1966). Europe Since Napoleon, England: Penguin Books.

Tihon, A. (2000). Christianisme et Société, Bruxelles: Publications des Facultés Universitaire Saint-Louis.

Ujah, E. Anaba, I. Duru, P. Onochiri, I et al. (January27, 2019). «US, EU, Falana, Civil Society Groups, Others Slam Buhari," Sunday Vanguard Vol. 24. No. 15934: 4-6

Online:

Bradney, A. "Religion and the Secular State in the United Kingdom," pdf. www.idrs.org

"Separating Church and State : The Case for Disestablishment," pdf article 